\section{Sister Mary Joseph's nodule: Three case reports} Andreas Larentzakis*1, Dimitrios Theodorou ${ }^{1}$, Klio Fili ${ }^{1}$, Anna Manataki ${ }^{2}$, Vasiliki Bizimi², Michael Tibishrani² and Stylianos Katsaragakis ${ }^{1}$

\author{
Address: ${ }^{1} 1$ st Department of Propaedeutic Surgery, Hippokrateion General Hospital, Athens Medical School, University of Athens, Q. Sofias 114 \\ av., 11527, Athens, Greece and 2Department of Radiology, 'Thriassio' General Hospital, G. Gennimata av., 19600, Attiki, Greece \\ Email: Andreas Larentzakis* - alarentz@med.uoa.gr; Dimitrios Theodorou - dtheodorou@ hippocratio.gr; Klio Fili - dimitheod@netscape.com; \\ Anna Manataki - amanat@easy.com; Vasiliki Bizimi - vbizim69@netscape.com; Michael Tibishrani - tibishrani@yahoo.com; \\ Stylianos Katsaragakis - skatsar@med.uoa.gr \\ * Corresponding author
}

Published: 24 September 2008

Cases Journal 2008, I:I82 doi:10.1186/1757-1626-1-182

This article is available from: http://www.casesjournal.com/content///I//82

(C) 2008 Larentzakis et al; licensee BioMed Central Ltd.

This is an Open Access article distributed under the terms of the Creative Commons Attribution License (http://creativecommons.org/licenses/by/2.0), which permits unrestricted use, distribution, and reproduction in any medium, provided the original work is properly cited.

Received: 31 May 2008

Accepted: 24 September 2008

\begin{abstract}
Background: An umbilical metastatic lesion is called 'Sister Mary Joseph's nodule'. It is an uncommon clinical or radiographic finding, and it is rare as the first sign of a malignant disease.

Case presentation: We report three cases of Sister Mary Joseph's nodule. In the three cases presented, the primary tumor was an adenocarcinona of the sigmoid colon, a carcinoma of the bladder, and an adenocarcinoma of the gallbladder, respectively.
\end{abstract}

Conclusion: The differential diagnosis of an umbilical lesion should always include metastatic disease apart from benign lesions and primary neoplasms.

Open Access 


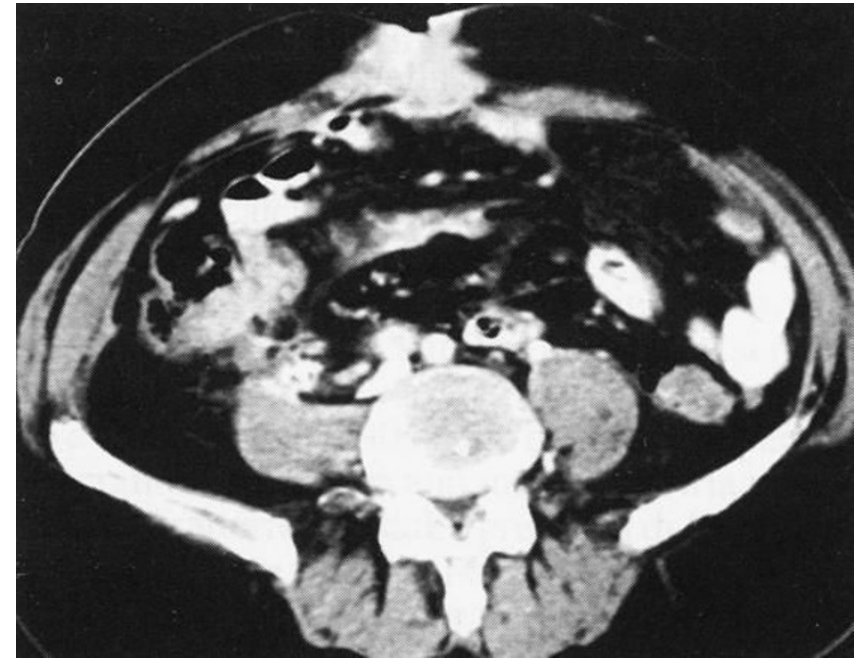

Figure I

CT-scan of the abdomen: This image shows an umbilical mass measured $3 \mathrm{~cm}$, with indefinite margins.

cell carcinoma. Further assessment with computed tomography (CT-scan) confirmed the presence of the tumor at the left lateral wall of the bladder, and revealed pelvic lymph nodes involvement and an umbilical mass measured $2 \mathrm{~cm}$ (Figure 2). Percutaneous biopsy of the umbilical mass also showed transitional cell carcinoma. Patient underwent cystectomy and chemotherapy.

\section{Case 3}

A 54-year old male presented with an umbilical painless mass. He was receiving medication for diabetes mellitus. Patient's physical examination revealed no other abnormality. Pathologic examination of percutaneous biopsy specimen showed malignant epithelial tumor, with characteristics of gall bladder or pancreatic origin adenocarci-

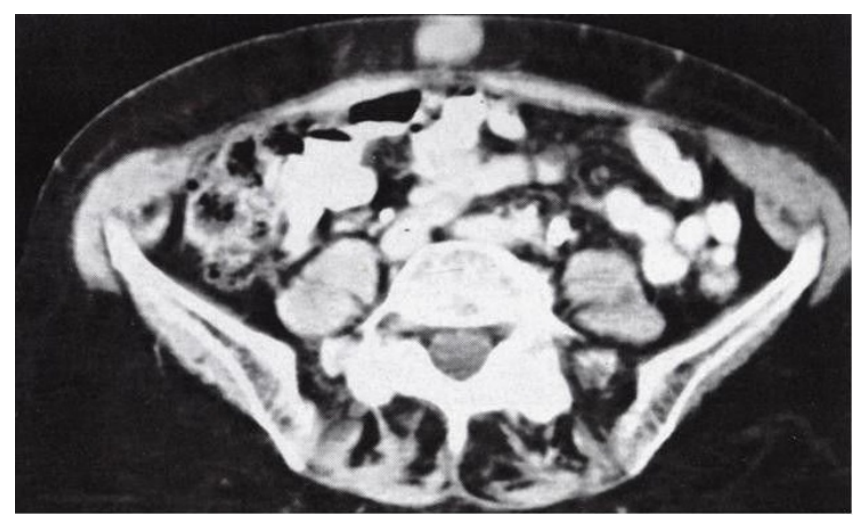

Figure 2

CT-scan of the abdomen: This image shows an oval umbilical mass measured $2 \mathrm{~cm}$. noma. Neither upper gastrointestinal endoscopy nor colonoscopy detected any abnormality. Computed tomography of the abdomen showed a gall bladder with increased wall thickness and intraluminal invasive mass, peritoneal lesions, ascites, and an umbilical mass involving the adjacent adipose tissue (Figure 3). Patient received surgical treatment. The pathologic examination of the surgical specimen showed adenocarcinoma of the gallbladder. Patient's further treatment was chemotherapy.

\section{Discussion}

The occurrence of Sister Mary Joseph's nodule is uncommon, and as first sign of malignancy is rare [2]. The intestinal and genitourinary tracts represent the most common, but not the only ones, primary malignant sites [3]. However, the study of an umbilical mass as unique clinical finding should be directed by the suspicion of being a metastatic deposit [4], having also in mind the potential of a primary malignant umbilical lesion or a benign disease [5]. In addition, an umbilical mass in a patient with known malignancy, especially of the abdomen, should be evaluated as potential spreading of the primary disease, a fact that can influence the therapeutic decision making $[4,6]$. Finally, the approach of surgery should be under careful consideration in these cases, because Sister Mary Joseph's nodule represents the spreading of a neoplasm, which is accompanied by low survival rates [4].

\section{Conclusion}

An umbilical mass can represent a benign lesion, such as a cyst or an abscess, but also a primary or metastatic malignant tumor. Although not common, the last two

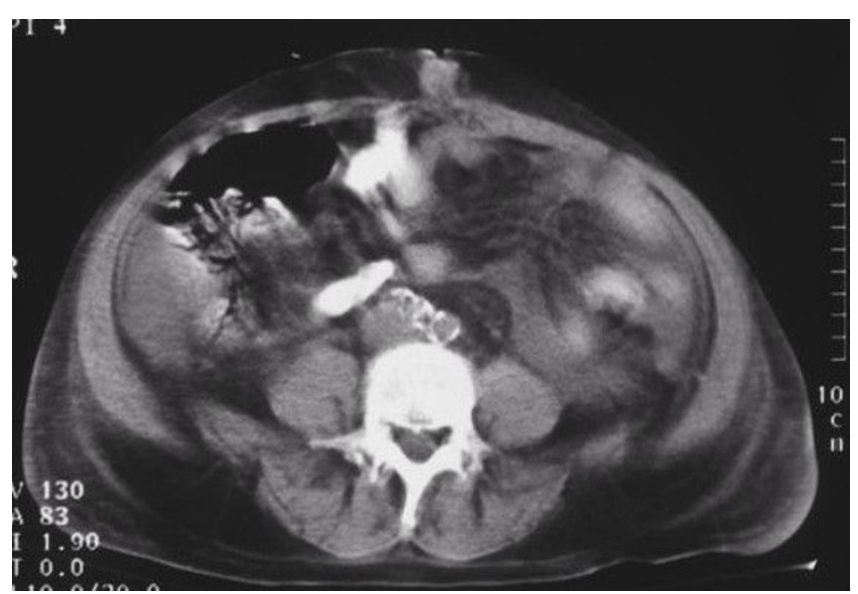

Figure 3

CT-scan of the abdomen: This image shows an umbilical mass measured $2.5 \mathrm{~cm}$, involving the adjacent adipose tissue. 
entities should be considered in the evaluation and management of the umbilical masses.

\section{Competing interests}

The authors declare that they have no competing interests.

\section{Authors' contributions}

AL contributed to the conception, design and drafting of the manuscript, as well as to the analysis and interpretation of data. DT contributed to the conception and design of the manuscript and revised it critically. KF contributed to acquisition of data and to the drafting of manuscript. AM contributed to acquisition of data and to the drafting of manuscript. VB contributed to acquisition of data and to the drafting of the manuscript. MT contributed to acquisition of data and to the drafting of the manuscript. SK contributed to the conception and design of the manuscript and revised it critically. All authors read and approved the final manuscript.

\section{Consent}

Written informed consent was obtained from the patient for publication of this case report and accompanying images. A copy of the written consent is available for review by the Editor-in-Chief of this journal.

\section{References}

I. Bailey, Hamilton : Demonstrations of Physical Signs in Clinical Surgery. I Ith edition. John Wright and Sons. Bristol; 1949:227.

2. Lookingbill D, Spangler N, Sexton FM: Skin involvement as the presenting sign of internal carcinoma. A retrospective study of 7316 cancer patients. J Am Acad Dermatol 1990, 22:19-26.

3. Galvan VG: Sister Mary Joseph's Nodule. Ann Intern Med 1998, I 28:4I0.

4. Gabriele R, Conte M, Egidi F, Borghese M: Umbilical metastases: current viewpoint. World J Sur Oncol 2005, 3:13.

5. Khati NJ, Enquist EG, Javitt MC: Imaging of the umbilicus and periumbilical region. Radiographics 1998, 18:413-31.

6. Schneider V, Smyczek B: Sister Mary Joseph's nodule. Diagnosis of umbilical metastases by fine needle aspiration. Acta Cytol 1990, 34:555-558.
Publish with Bio Med Central and every scientist can read your work free of charge

"BioMed Central will be the most significant development for disseminating the results of biomedical research in our lifetime. "

Sir Paul Nurse, Cancer Research UK

Your research papers will be:

- available free of charge to the entire biomedical community

- peer reviewed and published immediately upon acceptance

- cited in PubMed and archived on PubMed Central

- yours - you keep the copyright

Submit your manuscript here:

http://www.biomedcentral.com/info/publishing_adv.asp
BioMedcentral 